\title{
Institutions and Economic Performance: A Critical Evaluation of the Nigeria Economy
}

\author{
Okosu, Napoleon David \\ Department of Economics, Veritas University, Abuja, Nigeria
}

\begin{abstract}
The objective of this study is to critically evaluate the impact of institutions on the economic performance of Nigeria. To achieve this, annual time series data were employed from 1999 to 2020. Six institutional quality indicators of Political Stability Index, corruption perception index, Voice and Accountability, Rule of Law, Regulatory Quality, and Ease of Doing Business indicator, were employed as the independent variables while the dependent variable, economic performance was proxied by Gross Domestic Product (GDP) Per Capita. The result indicates that all the indicators of institutional quality have positive impact on economic performance in Nigeria in the period under review. Political Stability Index, Corruption Perception Index, Regulatory Quality and Ease of doing business have significant impact on economic performance while Voice and Accountability as well as Rule of Law had insignificant positive effect. The study concludes that there is the need for strong institutions in Nigeria as it engenders higher economic performance, thus noting that institution is the oil that lubricates the engine of economic growth and development in an economy.
\end{abstract}

Key Words: Institutionalist, Institutional Quality, Economic Performance, GPer Capita.

\section{INTRODUCTION}

$\mathrm{I}$ $\mathrm{n}$ recent times Nigeria economic growth has been low, the economy has suffered two recessions in 2017 and 2020 respectively and has exited these recessions. The economy had between 2002-2014 experienced an average of 7 percentage Gross Domestic Product (GDP) growth. Despite the growth in these years, there were no corresponding increase in standard of living and welfare of Nigerians. Several factors as been adduced to the poor economic transformation, but of key importance is the nature and characteristics of Institutions in Nigeria. Yildirim and Gokalp (2015) opine that institutions exert a significant impact on the performances of economic performance in nations through affecting the transaction costs by decreasing uncertainty, hence encouraging economic activity to productive sectors and by building trust. The establishment, functions, workings and development of institutions differ substantially among nations, these differences lead to different economic performances in nations and is the reason why we have some nations poor while others are rich.

North (1990), notes that institutions are the humanly devised constraints that build political, economic and social interaction. They comprise of both formal and informal constraints, the formal constraints deal with property rights, laws and the constitution and the informal relates to culture and customs, taboos and sanctions. Studies have showed that, strong institutions is a critical component in creating an enabling environment for the engine of economic success to spread to the poorer sections of the people in Sub Sahara Africa (SSA) (Thorbecke, 2013).

North \& Thomas (1973) contend that though innovations and factor accumulation could improve economic growth, the basic explanation of a nation's comparative economic growth is the difference in institutions. Thus, the quality of institutions such as level of corruption, political stability, and quality of regulations as well as the rule of law can substantially influence investments in physical and human capital, industrial production and technology which culminates to better economic performance.

Institutional economics correlates the source of poverty of developing nations to the absence of institutions that can solve low efficiency questions. Developing countries largely have institutions that are of low quality and do not support protecting property rights and productive investments. Hence it is expedient for them to initiate institutional reforms that would engender vibrant institutions that would subsequently bring about economic growth and development.

It is important to state that there is a debate on the form and function of institution, as Chang (2005) had observed that, since we do not have a consensus on the definition or what institution is, we can describe an institution by its function. He noted that to promote economic development, institutions have to perform some important functions and some forms of institutions exist that performs these functions best. However, Olaniyi (2001) opined that institutional forms may not be of much importance, since the same function can be achieved by separate institutional forms. He noted that specific form of institutions may not engender the needed or envisaged results, this is because failures where experience in various institutional transplantation carried out by colonial government in most countries of Africa.

Plethora of empirical literature have observe that countries with good level of freedom or elevated level of civil liberties "strong institutions" have high economic performance. As noted by the Organisation of Economic Cooperation and Development (2001) governance performances enhances nation's economic performance. Also, Stiglitz (2001) had revised Washington Consensus calling for good governance "quality institution" as a panacea to economic advancement. However, as observed by Radzeviča \& Bulderberga, (2018), there is no clear consensus on the influence of institutions on 
the economic growth, this is due to the fact that there is still lack of credible empirical evidence since it difficulty to actually measure institutions and establish causality

Nigeria has been adjudged the world capital of poverty by the data from World Poverty Clock and National Bureau of Statistics (NBS, 2020). The cause of poverty in developing countries as postulated by Institutional economist relates to the lack of institutions that provide solution of the problems of low efficiency. Largely underdeveloped nations have low quality institutions that do not succeed at encouraging productive investments and protection of property rights. In this circumstance the countries need to initiate institutional reforms and establish good institutions to engender economic development (Yildirim and Gokalp, 2015).

The prime objective of this study, therefore, is to empirically investigate the impact of institutions on the economic performance of the Nigerian from 1999 when Nigeria return to democracy to 2020.This is essential, as the results could assist government and policy makers on the way out of the current economic quagmire that has bedeviled the nation.

The remaining of this study is organized as follows. Section two provides a theoretical framework and literature review. Data and methodology are presented in Section three. Section four deals on the result presentation and discussion while Section five ends with conclusion with recommendations.

\subsection{Institution In Nigeria}

Here we consider some institution that are considered to be critical to accomplishing institutional change in Nigeria. Micro-level studies in combination of many empirical research had provided evidence that strongly support the assertion that institutions are important component in achieving development in different parts of the world. (Hall and Jones, 1999; Acemoglu, Johnson and Robinson, 2001)

After the return to civil rule from Military rule (1983-1999) than spanned over 16 years, the Nigerian economy was bedeviled with many challenges as successive military government had left many critical sectors unattended to. Thus by 1999 when political power was transferred to civilians, Nigeria was rated the second most corrupt country in the world by Transparency International's Corruption Perception Index. The new government move to stop this ugly tide by establishing the Independent Corrupt Practices Commission (ICPC) in 2000 through an act of parliament. ICPC is saddles with the responsibility of establishing and maintaining high moral and ethical standard by public officers, ensure that government business are conducted in high standard of public morality.

Also, the Economic and Financial Crimes Commission (EFCC) in 2004 was established to combat economic and financial crimes, prevent and investigate and prosecute as well as penalize economic and financial crimes. It is worth stating that one of the rationale for the creation of the EFCC was in response of pressure from the Financial Action Task Force
(FATF) which labelled Nigeria as one of 23 nations noncooperative in the global community's efforts to fight money laundering.

Another important institution is the Nigerian Financial Intelligence Unit (NFIU). The act was passed in 2004 and granted autonomy in 2018 in line with international best practices. NFIU is the Nigeria's central agency, saddled with the responsibility for the receipt and analysis of financial disclosure (Currency transaction reports and Suspicious transaction reports) and dissemination of intelligence generated there-from, to competent authorities. It also amongst others, Monitor Compliance with AML/CFT Requirements - to ensure compliance by reporting entities

Fiscal Responsibility Commission (FRC) was established in 2007 to ensure Fiscal Prudence and to promote economic stability in the business of Government. The commission is to ensure that policies around revenue-raising and resource allocation decisions as well as debt management decisions are undertaken in a prudent, transparent and timely fashion

In a nutshell, one can confidently state that Nigeria is not in dearth of institutions that are responsible for the ensuring prudence and accountability in resource utilization as other agencies existed, even prior to 1999. Some other institution that were in existence before 1999 were Code of Conduct Bureau, Public Complaints Commission, Financial Reporting Council of Nigeria (FRCN) and the Nigerian Polic Force.

According to Zimbauer (2001), several African countries are characterized by weak institutions with few exceptions. As observed by Olaniyi, (2001) reform of institutions in Africa has been experience mix results of successes and failure at a different degree in different time. He furthered cited Botswana and Mauritius as countries that have demonstrated capacity to build strong and effectives institutions on the basis of democracy and the rule of law.

\section{THEORITCAL FRAMEWORK AND LITERATURE REVIEW}

\subsection{New Institutional Economics Theory}

The New institutional economics (NIE) is considered as an interdisciplinary school that combines economics, organization theory, law, anthropology, sociology and political science, to comprehend the institutions of sociopolitical and business life. This School thought used inputs from various disciplines in social-science however, its principal language is economics. The aim of this School is to explain in clear terms what institutions are, how they arise, what purposes they serve, how they change and how - if at all - they should be reformed (Klein, 1999). The NIE avails a strong reply to the old allegation that mainstream economics (neo-classical) who took institutions as given. It is often either declined as a mix concept that puts together incompatible conflicting assumptions or it is championed and selectively instrumentalized as convenient catch-it-all ad-hocery (Zimbauer, 2001). 
NIE theory started with the writing of Ronald Coase, following his publications of "The Nature of the Firm" (1937) and "The Problem of Social Cost" (1960). He introduced the concept of transaction costs into economic analysis and maintained that without transaction costs, alternative property right assignments can lead to internalize conflicts and externalities. However, the term 'New Institutional Economics' was first coined by Oliver Williamson in 1975.

The NIE theory builds on the Old Institutional Economic theory that emphasized the importance of institution to the achievement of economic growth (Hodgson, 2004). It created some new ideas rooted on the old institutional economics theory. It is worth stating that NIE emphasized that institutions are endogenous critical factors that offers incentive structure for economic growth, noting that institutions do matter since they reduce uncertainty, lower transaction costs, internalize externalities and produce collective benefits from cooperation (North, 1990).

The core assumptions of NIE are imperfect information about the intentions and behaviour of other economic actors. This implies asymmetric information which causes monitoring and enforcement of agreement difficult. There is also issue of opportunism which Williamson (1985) described as "selfinterest with guile". This presents in form of shirking of responsibility; adverse selection; moral hazard; strategic default; free-riding and hold-up. Yet another assumption is bounded rationality which is due to reliance on conventions and norms.

NIE are of the opinion that institutions form in integral part that assist to deal with transaction costs. They vividly call on the State to act and not be neutral as it has the capacity of hindering or facilitating strong institutions, that there are zero transaction costs, and that actors have fixed preferences

The main tenet of NIE are to elucidate on what are institutions, how do they vary or rise, how do they affect the socio-politico and economic life.

With regards to the analytical approach, the NIE theory has three important characteristics.

a) it explains the economic activities based on the transaction costs approach. that individuals cannot rationally make best selection in the presence of transaction costs

b) It questions the full rationality assumption of neoclassical economic theory, accenting that human beings are bounded rationality rather than full rationality to optimize decision due to the constraints of information and cognitive capability of individuals.

c) it explains institutions in a way of individualism rather than holism. It regards the interaction of individuals as the main basics in elucidating the emergency and change of institutions (Hodgson, 2004) and (Ankarloo, 1999)
In recent times NIE has branched into many other distinct subfields, which includes transaction cost economics, property rights analysis, economic theory of contracts, the new institutional approach to economic history, the new institutional approach to political economics, and constitutional economics (Furubotn and Richter, 1998)

\subsection{Literature Review}

Samarasinghe, (2020) noted that differences in institutions indicates a direct nexus with difference in economic development. He stated that recognized political and economic institutions impacts the level of investments for human capital, physical capital and technology formation, which propels the capacity of good and service production in a particular country. Hence good institution boosts the economic development while bad institution propels economic stagnation or decline. Evidence from most developed nations experience the establishment of good institution while that of developing nations suffers from existence of bad institutions.

In their study, Epaphra and Kombe (2018) looked at the impact of institutions on African economic growth and their findings showed that institutions are important for Africa's economic development. Furthermore, Political Stability was found to be the most important element among the Institutional Quality Indicators that account for Africa's real GDP per capita development. The study also stated that the quality of institutions alone may not be sufficient for real GDP growth and hence urged structural transformation in the form of trade, labour force, fixed capital formation, and foreign direct investment liberalization.

Wanjuu and le Roux (2017) investigated the impact of economic institutions on economic growth in the Economic Community of West African States (ECOWAS). Their findings indicated that economic institutions promote economic growth in ECOWAS. The study found that strong quality economic institutions, private investments, government security, and fundamental economic and social infrastructure will all help to boost economic growth in the ECOWAS area. The conclusion was that a concerted effort should be employed to combat corruption in the region.

Nabila et al. (2015) provide evidence to suggest that institutional quality is a positive determinant of economic growth. It was further observed that there is a causality relationship between institutional quality and economic growth. This result is in tandem with Constantinos et al (2014) who find quality of institutional ecosystem to be a key factor of economic prosperity of Sudan.

Kilishi et al. (2013) researched on institutions and economic performance in Sub-Saharan Africa from 1996 to 2010. The results noted that institutions in sub-Saharan African have significant effect on the economic performance in SSA specifically quality of regulatory framework and the rule of law. Thus, they recommended improving the application of 
the rule of law, accountability and political stability as it would enhance economic performance.

Noting the essential roles that Institutions play in an economy, Baumol (1990) asserted to the fact that strong institution mitigants against rent seeking or organized crime that are occasioned by information asymmetry. Thus innovation is the only channel in which competition and dominance would be achieved.

Acemoglu et al. (2002) observed that there exists a nexus between macroeconomic volatility and institutions in developing nations. That Bad institution assists macroeconomic instability in these nations, and persons with power manipulate these bad institutions for their selfaggrandizement with the aim of perpetuating themselves in power

Forson et al. (2017) investigated the relationship between innovation and economic growth in Sub Sahara Africa, noted that innovation has a positive and significant impact on the growth trajectory of SSA though the impact appears very small, they recommended that proper coordination and allocating the right mix of financing option in supporting the activities of public organizations and parastatals should be pursued to enhance their effect on economic performance.

Ehighebolo and Braimah (2020), noted that there are many theoretical and empirical evidences that support the view that political institutions boost economic performance in emerging democracies. Using data from when the Military returned power to democratically elected government in Nigeria (1999 to 2018). It was observed that in the 19 years period of democratically elected government, there was consistent GDP growth from 1999 to 2002; fluctuating and declining growth from 2003 to 2018. The desired economic growth for Nigeria was somewhat a mirage and development was at best in snail speed.

Economic structures, according to Constantine (2017), are an important cause of economic performance because they control the rate of structural learning, influence institutional performance, affect income distribution, and direct political transitions, all of which lead to higher economic performance. As a result, economic structure and institutions are critical components, as markets cannot assure growth-enhancing transformations on their own.

Afonso (2020) applying the endogenous growth theory, observed that the accumulation of knowledge is the prime driver of growth. And Institutions are the mechanism for converting knowledge into new goods and services. He concluded that institutions contributed more than 0.3 percentage points to the estimated average annual growth rate of real output in 28 OECD countries between 2011 and 2017. Furthermore, he reinforced the hypothesis that improving the quality of institutions contribute positively to economic growth.
As noted by Udah and Ayara (2014) available traditional economic theory were not able to provide satisfactory clarification for the poor performance of developing countries including Nigeria despite experiencing increase in RGDP for a long period. The Neoclassical theory did not clearly provide the reasons why developing economies in spite widespread reforms to market economy were unsuccessful in achieving economic development. Hence, the authors interrogated the impact of institutions, governance structure and economic performance relationship in Nigeria. Findings shows that government effectiveness, voice and accountability, exert positive and significant relationship on economic performance.

Abubakar (2020) in his study ascertained the existence of directional effect of institutional quality through effective governance index to economic growth in Nigeria. The finding showed that economic growth responds positively and negative to the effect from the variables of domestic investment and foreign direct investment in a significant manner. Furthermore, the findings extend support to calls for quality institutions that can enhance both private and public enterprise to function efficiently for viable growth and development in Nigeria.

On the other, Institution may not always be an enabler of economic growth and development, as observed by institution may at times generate barriers or raise cost of participating in the market process. Institution may also lead entrepreneurs to unproductive activities such as rent seeking. The issue of rent seeking has also been highlighted as a problem in the Nigerian economy, as the Nigeria oil industry which is the main stay of the economy has established a crony capitalist economy of rent-seeker (Moghalu, 2021)

Various empirical literature exists to show that good and effective institution is a catalyze to economic performance and even leads to economic development. (Nawaz 2015; Langlois 2017), Put differently, the causal impact between institutions and economic performance studies have showed that a better institutions drives higher income rather than causation being in the opposite direction, (Acemoglu et al. 2001 and Rodrik et al. 2000 )

\section{METHODOLOGY}

This paper employed secondary data in its analysis. Specifically, time series data from 1999 to 2020 were utilized. The data were obtained from World Governance Indicators, World Development Index, CBN statistical bulletin, National Bureau of Statistics and Transparency International,

The dependent variable was Gross Domestic Product Per Capita (GDPPC), while the independent variables were Institutional quality indicators of Political Stability, Corruption Perception Index, Voice and Accountability, Regulatory Quality, Rule of law and Easy of Doing Business. This study will also seek to investigate the nexus between the independent variables and dependent variable. 
For stationarity test, the Augmented Dickey-Fuller (ADF) Unit Root Test was deployed, for the nexus between the dependent and independent variables, the correlation matrix was used. Co-integration test was performed using PhilipsOuliaris test to examine if the variables have a long-run equilibrium relationship. The Least Squares regression technique was used to determine the impact of institutional variables on GDP per capita. Next was the application of post estimation diagnostic test to check the robustness of the result.

\subsection{Model Specification}

In order to accomplish the prime objective of this paper, the model assumes a linear relationship. The linear specification is done to investigate the impact of Institution quality on economic performance of the Nigerian economy. A balanced datasets for the period 1999-2020 which consist of the annual data of selected relevant variables. The start date was chosen to captured the year Nigeria return to civilian rule after 16 year of dictatorial Military rule.

The functional and econometrics forms of the model are presented in Equation (1) and Equation (2) respectively, below:

\section{Functional Specification}

$\mathrm{GDPPC}=\mathrm{f}(\mathrm{PSI}, \mathrm{COR}, \mathrm{VA}, \mathrm{RL}, \mathrm{EDB}, \mathrm{REQ})$

Transformed to econometric terms as
$\mathrm{GDPPC}=\beta_{0}+\beta_{1} \mathrm{PSI}+\beta_{2} \mathrm{COR}+\beta_{3} \mathrm{VA}+\beta_{4} \mathrm{RL}+\beta_{5} \mathrm{EDB}+$ $\beta_{6} \mathrm{REQ}+\mathrm{U}_{\mathrm{t}} \ldots(\mathrm{-})$

Where:

PSI $=$ Political Stability Index

$\mathrm{COR}=$ Corruption Perception Index

$\mathrm{VA}=$ Voice and Accountability

$\mathrm{RL}=$ Rule of Law

$\mathrm{EDB}=$ Ease of Doing Business

$\mathrm{REQ}=$ Regulatory Quality

$\beta_{0}$ is a constant parameter

$\beta_{1,}, \beta_{2}, \beta_{3}, \beta_{4}, \beta_{5}, \beta_{6}$ are parameters to be estimated

Apriori expectation

$\beta_{0}>0, \beta_{1}>0, \beta_{2}>0, \beta_{3}>0, \beta_{4}>0, \beta_{5}>0, \beta_{6}>0$

\section{RESULTS AND DISCUSSIONS}

\subsection{Summary Statistics}

The Summary statistics as derived through E-Views 11.0 shows the Mean, Median, Maximum, Minimum, Standard Deviation, Skewedness, Kurtoise, Jacque-Bera and Probability of each of the variables as presented below:

Table 1 Summary Statistics

\begin{tabular}{|c|c|c|c|c|c|c|c|}
\hline & $\mathrm{COR}$ & $\mathrm{EDB}$ & GDPPC & PSI & REQ & RL & VA \\
\hline Mean & 22.04545 & 136.3636 & 70234.71 & 1.585909 & -0.861364 & -1.146364 & -0.671818 \\
\hline Median & 24.50000 & 136.0000 & 69142.04 & 0.245000 & -0.825000 & -1.105000 & -0.675000 \\
\hline Maximum & 28.00000 & 163.0000 & 101881.5 & 13.59000 & -0.650000 & -0.870000 & -0.320000 \\
\hline Minimum & 10.00000 & 123.0000 & 38691.06 & -2.030000 & -1.350000 & -1.430000 & -1.550000 \\
\hline Std. Dev. & 5.576116 & 9.509621 & 19626.31 & 4.298151 & 0.186402 & 0.178073 & 0.278219 \\
\hline Skewness & -0.825933 & 0.889528 & 0.012262 & 1.283699 & -1.416165 & -0.212367 & -1.348648 \\
\hline Kurtosis & 2.298048 & 3.993106 & 1.931385 & 3.820032 & 4.230286 & 1.970641 & 5.629396 \\
\hline Jarque-Bera & 2.952948 & 3.805360 & 1.047327 & 6.658655 & 8.741059 & 1.136647 & 13.00670 \\
\hline Probability & 0.228442 & 0.149168 & 0.592346 & 0.035817 & 0.012645 & 0.566474 & 0.001498 \\
\hline Sum & 485.0000 & 3000.000 & 1545164. & 34.89000 & -18.95000 & -25.22000 & -14.78000 \\
\hline Sum Sq. Dev. & 652.9545 & 1899.091 & $8.09 \mathrm{E}+09$ & 387.9561 & 0.729659 & 0.665909 & 1.625527 \\
\hline Observations & 22 & 22 & 22 & 22 & 22 & 22 & 22 \\
\hline
\end{tabular}

Source: Author's own computation using E-Views Software, Version 11

It was observed from the above normality test with reference to the Jarque-Bera estimates and probability value that COR, EDB, GDPPC and RL were normally distributed due to their high probability values of $0.228442,0.149168,0.592346$ and
0.566474 which were higher than the probability of 0.05 . Conversely, it was observed that, PSI, REQ and VA were not normally distributed due to their low probability values of $0.035817,0.012645$ and 0.001498 respectively which is lower 
than the probability value of 0.05 (5 percent level of significance). Normality or non-normality of the variables does not affect the parameter estimates and data analysis as cited by the central limit theorem that non-normality of a variable does not affect mean values as it only shows the pattern of distribution or spread of the variable

\subsubsection{Trend Analysis}
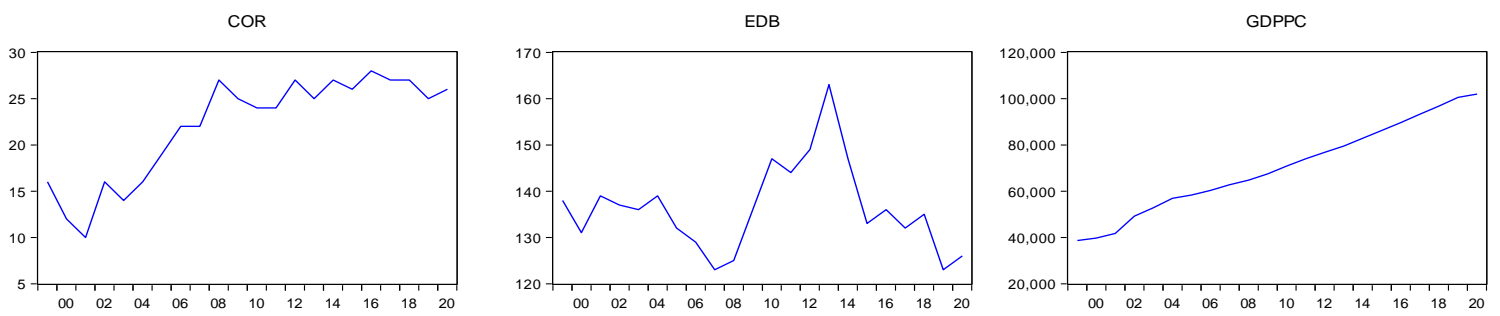

PSI

REQ
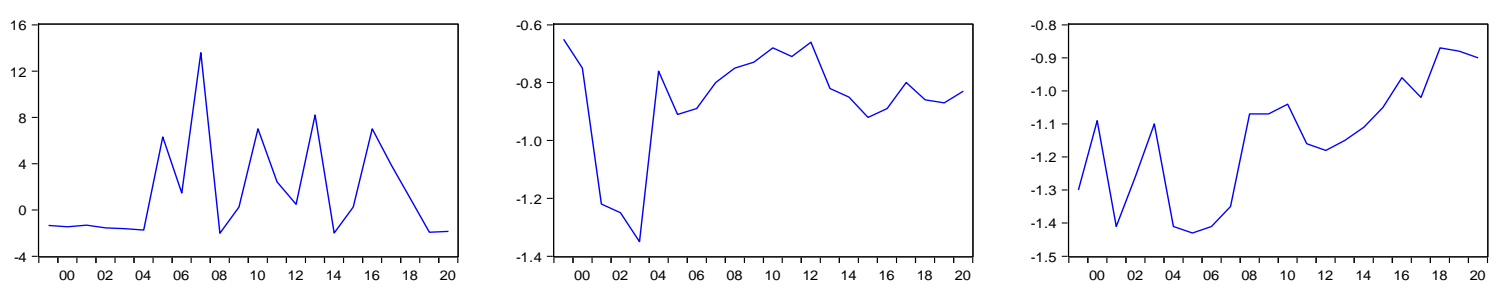

VA

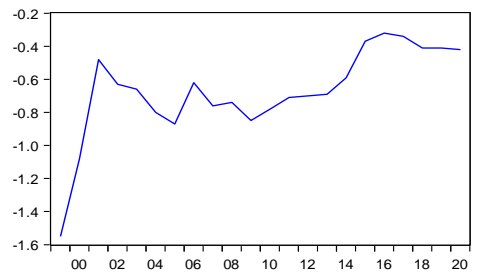

Figure 1.0 Graphical Analysis

Graphically, the trend analyses showed that the variables fluctuate at one point or the other during the period under review. This was attributed to the effects of international economic events, government policy and socioeconomic conditions that would have had attendant effects on some of the variables.

Table 2 Correlation Matrix

\begin{tabular}{|c|c|c|c|c|c|c|c|}
\hline VARIABLES & GDPPC & PSI & COR & VA & RL & EDB & REQ \\
\hline GDPPC & 1 & 0.131653 & 0.853111 & 0.709701 & 0.737311 & -0.03856 & 0.235482 \\
\hline PSI & 0.131653 & 1 & 0.260525 & 0.052004 & -0.1457 & 0.140004 & 0.212179 \\
\hline COR & 0.853111 & 0.260525 & 1 & 0.466306 & 0.593052 & 0.051759 & 0.481568 \\
\hline VA & 0.709701 & 0.052004 & 0.466306 & 1 & 0.448232 & -0.12645 & -0.36311 \\
\hline RL & 0.737311 & -0.1457 & 0.593052 & 0.448232 & 1 & -0.10036 & 0.148925 \\
\hline EDB & -0.03856 & 0.140004 & 0.051759 & -0.12645 & -0.10036 & 1 & 0.103987 \\
\hline REQ & 0.235482 & 0.212179 & 0.481568 & -0.36311 & 0.148925 & 0.103987 & 1 \\
\hline
\end{tabular}

Source: Author's own computation using E-Views Software, Version 9.0

From Table 2 above, the correlation result shows a strong and positive correlation exist between, Corruption perception index (COR), Voice and Accountability (VA) and Rule of Law (RL) on economic growth in Nigeria, On the other hand, Ease of doing Business (EDB) has a weak negative relationship with economic growth. The result also depicted that there is a positive nexus between Political Stability Index
(PSI), Regulatory quality (Req) and economic growth, although with weak effect.

\subsubsection{Unit Root Test}

The Augmented Dickey-Fuller test was used to test for unit root. All the variables were regressed on trend and intercept to determine if they have trend, it was discovered that the five 
variables have trend and intercept, hence the unit root test involve trend and intercept. The result is presented:

Table 3: Unit Root Stationarity Result

\begin{tabular}{|c|c|c|c|}
\hline Variable & ADF Statistics & Prob. & Stationary Status \\
\hline COR & -6.1719 & 0.0001 & $\mathrm{I}(1)$ \\
\hline EDB & -4.5617 & 0.0001 & $\mathrm{I}(1)$ \\
\hline GDPPC & -4.0332 & 0.0062 & $\mathrm{I}(1)$ \\
\hline PSI & -4.0567 & 0.0003 & $\mathrm{I}(0)$ \\
\hline REQ & -4.9935 & 0.0000 & $\mathrm{I}(1)$ \\
\hline RL & -6.2468 & 0.0000 & $\mathrm{I}(1)$ \\
\hline VA & -4.1511 & 0.0045 & $\mathrm{I}(0)$ \\
\hline
\end{tabular}

The critical values for rejection of hypothesis of unit root were from MacKinnon (1991) as reported in e-views 11.0.

Source: Author's Computation

The seven variables (COR, EDB, GDPPC, PSI, REQ, RL and VA) underwent unit root test using the Augmented DickeyFuller (ADF) test. PSI and VA were stationary at level (I (0)) the remaining variables COR, EDB, GDPPC, REQ and RL were stationary at first difference (I(1)).

\subsubsection{Co-Integration Test}

Table 4: Phillips-Ouliaris Co-Integration Test Result

\begin{tabular}{|c|c|c|c|}
\hline \multicolumn{3}{|c|}{ Null Hypothesis: the residuual series has a unit root } & \\
\hline \multicolumn{3}{|c|}{ Exogenous: None } & \\
\hline \multicolumn{4}{|c|}{ Bandwidth: 2 (Newey-West automatic) using Bartlett kernel } \\
\hline & & Adj. t-Stat & Prob.* \\
\hline \multicolumn{2}{|c|}{ test statistic } & -3.075830 & 0.0038 \\
\hline \multirow[t]{3}{*}{ Test critical values: } & $1 \%$ level & -2.679735 & \\
\hline & $5 \%$ level & -1.958088 & \\
\hline & $10 \%$ level & -1.607830 & \\
\hline \multicolumn{3}{|c|}{ *MacKinnon (1996) one-sided p-values. } & \\
\hline \multicolumn{3}{|c|}{ Residual variance (no correction) } & $\begin{array}{c}2912062 \\
5\end{array}$ \\
\hline \multicolumn{3}{|c|}{ HAC corrected variance (Bartlett kernel) } & $\begin{array}{c}3746226 \\
5\end{array}$ \\
\hline
\end{tabular}

Source: Author's computation from E-Views 11.0, 2021.

From table 4 , the result indicated that the variables are cointegrated. The tau-statistic for the Phillips-Ouliaris statistics is given as -3.075830 and the probability value of tau-statistic is 0.0038 (lower than 0.01 ie $1 \%$ level of significance) indicating that the variables are cointegrated (Phillips \& Ouliaris, 1990). The result confirms the presence of a long-run equilibrium relationship between GDPPC COR, $\mathrm{EDB}, \mathrm{PSI}, \mathrm{REQ}, \mathrm{RL}$ and VA for the period under consideration in Nigeria.
Table 5 Regression Result Dependent Variable: GDPPC

\begin{tabular}{|c|c|c|c|c|}
\hline $\begin{array}{c}\text { Independent } \\
\text { Variables } \\
\end{array}$ & Coefficient & $\begin{array}{c}\text { Standard } \\
\text { Error }\end{array}$ & t-Statistic & Probability \\
\hline PSI & 43.77255 & 407.4536 & 0.107430 & 0.9159 \\
\hline $\mathrm{COR}$ & 1331.469 & 567.7978 & 2.344971 & 0.0332 \\
\hline VA & 33437.66 & 9882.958 & 3.383365 & 0.0041 \\
\hline RL & 30505.16 & 12103.62 & 2.520334 & 0.0235 \\
\hline EDB & 18.51035 & 168.0412 & 0.110154 & 0.9137 \\
\hline REQ & 18819.05 & 14646.74 & 1.284863 & 0.2183 \\
\hline $\mathrm{C}$ & 111920.8 & 37775.05 & 2.962824 & 0.0097 \\
\hline \multicolumn{2}{|c|}{ Model Evaluation Criteria } & & & \\
\hline $\mathbf{R}^{2}$ & 0.906218 & & & \\
\hline Adjusted $\mathbf{R}^{2}$ & 0.868706 & & & \\
\hline F test & $\begin{array}{c}24.15770 \\
(0.000001)\end{array}$ & & & \\
\hline
\end{tabular}

Source: Author's Computation

From table 5, a unit change in Political Stability Index (PSI) will lead to 43.77255 unit change in Gross Domestic Product Per Capita (GDPPC), while holding other variables constant. The positive sign on satisfy apriori expectation. However, the high probability value of 0.9159 when compared to the conventional level of significance of 0.05 (5 percent level of significance) denotes the impact is insignificant.

Also, a unit change in COR (Corruption Perception Index), will results in increase in GDPPC by approximately 1331.469 units, while holding other variables constant. The result indicated that an increase in clean institution (i.e reduction in corruption) will improve economic growth. The lower probability value of 0.0332 when compared to the conventional level of significance of 0.05 denotes the impact is significant.

Furthermore, a unit change in VA (Voice and Accountability), will results in increase in GDPPC by approximately 33437.66 units, while holding other variables constant. The positive sign on VA satisfy apriori expectation. The lower probability value of the parameters given as 0.0041 when compared to the conventional level of significance denotes the impact is significant.

A unit change in RL (Rule of Law), will results in increase in GDPPC by approximately 30505.16 units, while holding other variables constant. The positive sign on RL satisfy apriori expectation. The lower probability value of the parameters given as 0.0235 when compared to the conventional level of significance denotes the impact is significant.

Finally, an increase in EDB (Ease of Doing Business) and REQ (regulatory Quality) leads to 18.51035 and 18819.05 unit increase in GDPPC respectively. The results conform with a priori expectation but are statistically insignificant as indicated by their respective high probability values of 0.9137 and 0.2183 which were greater than 5 percent level of significance. 
From model evaluation criteria, the correlation of determination $\left(\mathrm{R}^{2}\right)$ result showed that about 91 percent changes in GDPPC is accounted for by the explanatory variables. The F-statistic also indicated that the model is significant at 5 percent given the probability of $\mathrm{F}$ statistic as 0.000000 (less than 0.05).

\subsection{Diagnostic test}

\section{Normality Test}

The Jarque Bera (J-B) Normality test was used to test if the residual of the regression is normally distributed. If the Probability value of the computed Jarque Bera (J-B) statistics is greater than 0.05 then the residual of the regression equation is normally distributed at $1 \%$ level of significance.

Table 6 Jarque Bera (J-B) test for normal data

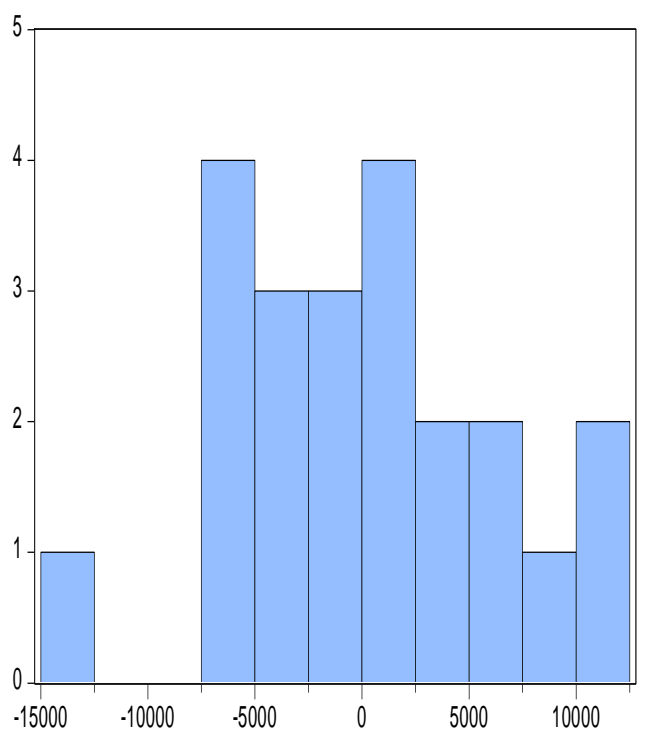

\begin{tabular}{|lr}
\hline Series: Residuals \\
Sample 1999 2020 \\
Observations 22 \\
& \\
Mean & $1.75 e-11$ \\
Median & 34.12510 \\
Maximum & 10173.93 \\
Minimum & -13783.56 \\
Std. Dev. & 5981.634 \\
Skewness & -0.102154 \\
Kurtosis & 2.758242 \\
& \\
Jarque-Bera & 0.091840 \\
Probability & 0.955118 \\
\hline
\end{tabular}

Source: Author's Computation (2021)

The Jarque Bera (J-B) statistic is 0.091840 and the probability value is greater than 0.05 at 0.955118 , hence we accept Ho which states that the residual from the regression interpreted above is normally distributed at $5 \%$ level of significance.

\section{Serial Correlation Test}

To test for serial correlation that is constant variance of the error term in the regression, the Breusch-Godfrey test of serial correlation was deployed. If the Probability value of the computed Chi-Square statistics is greater than 0.05 then the variance of the error term are not serially correlated.

Table 7 Breusch-Godfrey test of serial correlation

\begin{tabular}{|c|c|c|c|}
\hline \multicolumn{3}{|c|}{ Breusch-Godfrey Serial Correlation LM Test: } & \\
\hline F-statistic & 1.304703 & Prob. F(2,13) & 0.3045 \\
\hline Obs*R-squared & 3.677715 & Prob. Chi-Square(2) & 0.1590 \\
\hline
\end{tabular}

Source: Author's Computation (2021)
From the observed $R^{2}$ is 3.677715 with 2 and 13 degree of freedom, the probability value is greater than 0.01 which is 0.1590 , hence we accept Ho which states that the error term is not serially correlated at $5 \%$ level of significance.

\section{Homoscedasticity Test}

To test for Homoscedasticity that is constant variance of the error term in the regression, the Breusch-Pagan-Godfrey test of Homoscedasticity was used. If the Probability value of the computed Chi-Square statistics is greater than 0.05 then the variance of the error term is homoscedastic.

Table 8 Breusch-Pagan-Godfrey Test

\begin{tabular}{|c|c|c|c|}
\hline \multicolumn{4}{|c|}{ Heteroskedasticity Test: Breusch-Pagan-Godfrey } \\
\hline F-statistic & 1.558907 & Prob. F(6,15) & 0.2265 \\
\hline Obs*R-squared & 8.449553 & Prob. Chi-Square(6) & 0.2070 \\
\hline $\begin{array}{c}\text { Scaled explained } \\
\text { SS }\end{array}$ & 3.453183 & Prob. Chi-Square(6) & 0.7502 \\
\hline
\end{tabular}

Source: Author's Computation (2021)

The observed $\mathrm{R}^{2}$ is 3.453183 with 6 degree of freedom, the probability value is greater than 0.05 which is 0.2070 , hence we accept Ho which states that the error term is homoscedastic at $5 \%$ level of significance.

Regression Specification Error Test (RESET)

Table 9: Ramsey RESET Test

\begin{tabular}{|c|c|c|c|}
\hline \multicolumn{3}{|c|}{ Ramsey RESET Test } & \\
\hline \multicolumn{3}{|c|}{ Equation: UNTITLED } & \\
\hline \multicolumn{4}{|c|}{ Specification: GDPPC EDB COR PSI REQ RL VA C } \\
\hline \multicolumn{4}{|c|}{ Omitted Variables: Squares of fitted values } \\
\hline & Value & Df & $\begin{array}{c}\text { Probabilit } \\
y\end{array}$ \\
\hline t-statistic & 1.595614 & 14 & 0.1329 \\
\hline F-statistic & 2.545983 & $(1,14)$ & 0.1329 \\
\hline Likelihood ratio & 3.675892 & 1 & 0.0552 \\
\hline \multicolumn{4}{|c|}{ F-test summary: } \\
\hline & Sum of Sq. & Df & $\begin{array}{c}\text { Mean } \\
\text { Squares }\end{array}$ \\
\hline Test SSR & $1.16 \mathrm{E}+08$ & 1 & $1.16 \mathrm{E}+08$ \\
\hline Restricted SSR & $7.51 \mathrm{E}+08$ & 15 & 50091917 \\
\hline Unrestricted SSR & $6.36 \mathrm{E}+08$ & 14 & 45411552 \\
\hline \multicolumn{4}{|c|}{ LR test summary: } \\
\hline & Value & $\mathrm{Df}$ & \\
\hline Restricted LogL & -222.0268 & 15 & \\
\hline Unrestricted $\log \mathrm{L}$ & -220.1889 & 14 & \\
\hline
\end{tabular}

Source: Author's Computation (2021)

The Ramsey RESET result indicated that the regression model is the correctly specified. The F statistic and the Likelihood Ratio statistic showed that the regression equation is correct given their probability value of 0.1329 and 0.0552 which were higher than 0.05 respectively. 


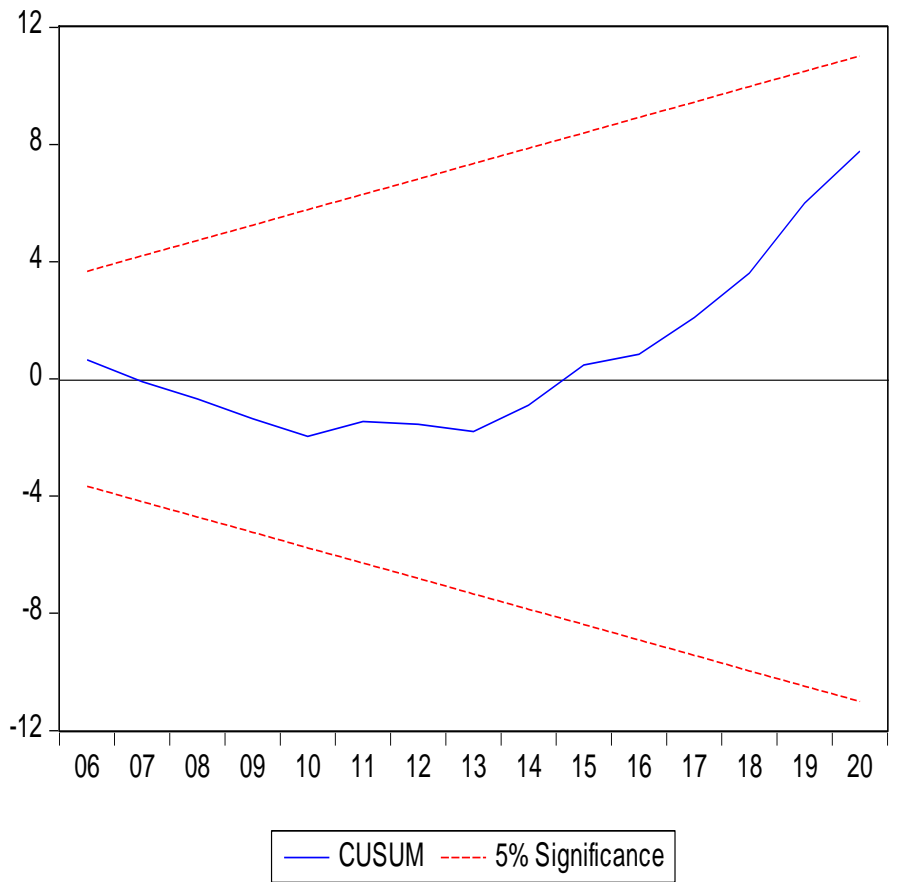

Figure 2 CUSUM TEST

The stability of the regression coefficients is tested using the cumulative sum (CUSUM) of the recursive residual test for structural stability. Plots of the CUSUM show that the regression equation seems stable given that the CUSUM test statistics did not exceed the $5 \%$ level of significance boundary.

\section{CONCLUSION AND RECOMMENDATION}

\subsection{Conclusion}

This study aims at examining the impact of institutions on economic performance of Nigeria, using data from 1999 to 2020. The independent variable of the study were six institutional quality indicators of Political Stability Index, corruption perception index, Voice and Accountability, Rule of Law, Regulatory Quality and Ease of Doing Business while economic performance was proxied by Gross Domestic Product Per Capital (GDPPC). The descriptive statistics, trend analysis, correlation matrix was performed to ascertain the relations between the dependent and independent variables. Furthermore, Unit roots test was carried out using Augmented Dicken Fuller and Phillips-Ouliaris Co-Integration Test, then Ordinary Least Square estimation technique was applied. Finally, some post diagnostic tests were performed these includes the Breusch-Godfrey Serial Correlation LM Test and Breusch-Pagan-Godfrey Test and the results indicates that no autocorrelation and no hetroscedasticity exist in the model. The Cusum test satisfied that the model is stable, also the Ramsey RESET result revealed that the regression model is the correctly specified.

Consequent upon the findings from this study, we can conclude that, institutional qualities indicators have positive nexus with economic Performance in Nigeria. As observed, corruption perception index, Political Stability, regulatory quality, Voice and accountability, and rule of law are prime determinants of economic performance in Nigeria, though Voice and Accountability, and Rule of Law produced positive impacts that were insignificant. This implies that Nigeria's lack of effective institutions, causes poor economic performance, thus institution is the oil that lubricates the engine of economic growth and development.

\subsection{Recommendation}

In the light of the above findings and conclusion from this study thereof, the following policy implications and recommendations are adduced as follows:

1. Deliberate efforts should be made to strengthen institutions in Nigeria. Critical Institution should be ring-fenced from political interference. The Country need strong institutions not strong men or strong leaders. Laws should be enacted to engender strong and virile institutions that can say no to bad leadership when it is right to do so.

2. The fight against corruption should be sustained and taken to another level. Relevant institutions should also focus on predicated offences and not rely on mainly on ex-post action.

3. Adequate deterrence should be instituted and enforce, as lack of it, brews corruption and the lifestyle of impunities, also the long arm of the law should be allowed to stretched further during and after service for public office holders.

\section{REFERENCES}

[1] Abubakar, S (2020), Institutional Quality and Economic Growth: Evidence from Nigeria. African Journal of Economic Review, Volume VIII, Issue I, January 202048

[2] Acemoglu D., Johnson S. and Robinson J. A. (2001). The Colonial Origins of Comparative Development: An Empirical Investigation. American Economic Review, 91, 1369-1401.

[3] Acemoglu D., Johnson S. and Robinson J. A. (2002). Reversal of Fortune: Geography and Institutions in the making of the modern World Income Distribution. Quarterly Journal of Economics, 117, 1231-1294.

[4] Acemoglu, D., Johnson, S., \& Robinson, J.A. (2005). Institutions as the fundamental cause of longrun growth. In: Aghion, P., \& Durlauf, S.N. (Eds.). Handbook of Economic Growth (pp. 385472), Vol. 1, Part 1, Elsevier.

[5] Acemoglu, D., Johnson, S., \& Robinson, J.A. (2005). The rise of Europe: Atlantic trade, institutional change and economic growth. American Economic Review, 95(3), 546-579.

[6] Afonso, O (2020): The impact of institutions on economic growth in OECD countries, Applied Economics Letters, DOI: 10.1080/13504851.2020.1855304

[7] Ankarloo, D (1999) "Institutions", What Is In a Word? A Critique of the New Institutional Economics. Department of Economic History, Lund University, 1999. Research output: Thesis > Doctoral Thesis (monograph

[8] Barro, R. \& Lee, J. (1993). Losers and winners in economic growth (NBER Working Paper, No. 4341).

[9] Barro, R. J. \& Sala-i-Martin, X. (1997). Technological diffusion, convergence, and growth. Journal of Economic Growth, 2(1), 126.

[10] Barro, R. J. (1990). Government spending in a simple model of endogenous growth. Journal of Political Economy, 98(2), 103-125. 
[11] Baumol, W.J (1990). "Entrepreneurship: Productive, Unproductive, and Destructive," Journal of Political Economy, 98, 5, part 1 (October 1990), pp. 893-921

[12] Chang H. (2005. Understanding the Relationship between Institutions and Economic Development - Some Key Theoretical Issues Paper to be presented at the WIDER Jubilee conference, 1718 June, 2005, WIDER, Helsinki

[13] Constantine, C (2017). Economic Structures, Institutions, and Economic Performance. Journal of Economic Structure Constantine Economic Structures (2017) 6:2 DOI 10.1186/s40008-017-0063-1

[14] Constantinos A., Persefoni T. and Hashim R.O. (2014). Institutional Quality and Economic Growth: Empirical Evidence from the Sudanese Economy. Economic Annals, 59(203).

[15] Ehighebolo, I. A and Braimah, M.O (2020), The Role of Political Institutions in Economic Growth and Development of Nigeria. Journal of Economics and Sustainable Development ISSN 22221700 (Paper) ISSN 2222-2855 (Online) Vol.11, No.4, 2020

[16] Financial Nigeria August 2021 Africa's premier Development and Finance Journal

[17] Forson, J.A., Opukah, R.A, \& Peng, Z (2017). Innovation, Institutions and Economic Growth in Sub-Sahara Africa - an IV Estimation of a Panel Threshold Model. Online at https://mpra.ub.uni-muenchen.de/103063/ MPRA Paper No. 103063, posted 28 Sep 2020 15:44 UTC

[18] Furubotn, E.G. \& Pejovich, S. (1972). Property Rights and Economic Theory: A Survey of Recent Literature. Journal of Economic Literature, 10(4), 1137-1162

[19] Furubotn, E.G \& Richter. R A. (1998). Institutions and Economic Theory: The Contribution of the New Institutional Economics. University of Michigan Press

[20] Giavazzi, F. \& Guido Tabellini, G. (2005). Economic and political liberalizations. Journal of Monetary Economics, 52(7), 1297-1330.

[21] Hall, R. E. \& Jones, C. I. (1999). Why do some countries produce so much more output per worker than others?. Quarterly Journal of Economics, 114(1), 83-116. jstor.org/stable/2586948.

[22] Hodgson, G. M (2004) The Evolution of Institutional Economics: Agency, Structure and Darwinism in American Institutionalism. London and New York: Routledge, 2004.

[23] Kilishi, A.A, Mobolaji, H.I, Yaru, M.A \& Yakubu, A.T (2013). Institutions and Economic Performance in Sub-Saharan Africa: A Dynamic Panel Data Analysis. Journal of African Development Fall 2013 | Volume 15

[24] Klein, D. (1999) If Government is So Villainous, How Come Government Officials Don't Seem Like Villains? Economics and Philosophy

[25] Langlois, R.N. (2017). The institutional approach to Economic Histrory: Connecting the two Strands. Journal of Comparative Economics 45 (1), 201-212

[26] Mauro, P. (1995). Corruption and growth. Quarterly Journal of Economics, 110(3), 681-712. jstor.org/stable/2946696

[27] Nabila A., Shazia Q. and Muhammad N. (2015). Institutional Quality and Economic Growth: Panel ARDL Analysis for selected Developing Economies of Asia. South Asian Studies, 30 (2), 381403

[28] Nawaz, S. (2015), Growth effects of Institutions: A disaggregated analysis. Economic Modelling 45, 118-126

[29] North, D. C. \& Thomas, R. P. (1973). The rise of the western world: A new economic history. Cambridge: Cambridge University Press

[30] North, D. C. (1990), Institutions, Institutional Change and Economic Performance, Cambridge University Press, Cambridge

[31] North D.C. (2005). Understanding the Process of Economic Change. New Jersey: Princeton University Press.

[32] Olaniyi O. (2001) Lectures on Institutions and Economic Development. Lectures delivered at the master in management for development program of the Catholic University of Millan, Castel gandolfo campus

[33] Phillips, P \& Ouliaris, S (1990). Asymptotic Properties of Residual Based Tests for Cointegration. Econometrica, Vol. 58, Issue 1, 165-93
[34] Powelson J.P. (1972). Institutions of Economic Growth: A theory of Conflict Management in Developing Countries. New Jersey: Princeton University Press.

[35] Radzeviča, A.M., Bulderberga, K., 2018. The role of institutional quality in economic growth: implications for the Baltic States. Unpublished Thesis in Stockholm School of Economics, SSE RIGA.

[36] Rodrik D. (2000). Institutions for high-quality growth: What they are and how to acquire them. Studies in Comparative International Development, 35(3), 3-31.

[37] Roll, R. \& Talbott, J. (2002). Policy research and analysis. The heritage Foundation.

[38] Samarasinghe, T (2020). The relationship between institutions and economic development. Munich Personal RePEc Archive. https://mpra.ub.uni-muenchen.de/97755/ MPRA Paper No. 97755

[39] Sokoloff, K. L. \& Engerman, S. L. (2000). Institutions, factor endowments, and paths of development in the new world. Journal of Economic Perspectives, 14(3), 217-232. doi.10.1257/jep.14.3.217

[40] Sethuraman, T.V (1970). Institutional Financing of Economic Development in India. Delhi Vikas Publications.

[41] Thorbecke E. (2013). Institutions for Inclusive Growth and Development in Sub-Saharan Africa. A paper presented at the JICA Conference, SOAS, University of London.

[42] Udah, E.B., Ayara, N., 2014. Institutions, governance structure and economic performance nexus in Nigeria. Journal of Economics and Sustainable Development. 5 (3).

[43] XU Jianing (2020) The Economic Impact of Malaysia's Institution on the Failure of the Wawasan 2020. Journalism, Xiamen University Selangor, Sepang, 43900, Malaysia. E3S Web of Conferences 214, 02005 (2020)

[44] Wanjuu, L.Z and le Roux, P (2017) Economic institutions and economic growth: Empirical evidence from the Economic Community of West African States. South African Journal of Economic and Management Sciences ISSN: (Online) 2222-3436, (Print) 1015-8812

[45] Williamson, O. (1975). Markets and hierarchies, analysis and antitrust implications: A study in the economics of internal organization. New York: Free Press.

[46] Williamson, O. (1985). The economic institutions of capitalism: Firms, markets, relational contracting. New York: Free Press.

[47] Zimbauer, D. (2001). "From Neo-classical Economics to New Institutional Economics and Beyond - Prospects for an Interdisciplinary Research Programme? Working Paper Series LSE Development Studies Institute London School of Economics and Political Science No.01-12 